\title{
Synergistic Effect of Fungal Consortia and C/N Ratio Variation on Rice Straw Degradation
}

\author{
Sheetal Barapatre $\dagger$, Mansi Rastogi, Babita Khosla and Meenakshi Nandal \\ Department of Environmental Sciences, Maharshi Dayanand University, Rohtak, Haryana, India \\ †Corresponding author: Sheetal Barapatre; barapatresheetal26@gmail.com
}

Nat. Env. \& Poll. Tech.

Website: www.neptjournal.com

Received: 16-02-2020

Revised: 24-02-2020

Accepted: $15-04-2020$

\section{Key Words:}

Aspergillus strains

Composting

Fungal consortia

Germination index

Phytotoxicity

Solanum lycopersicum

\begin{abstract}
In this study, the efficiency of fungal consortia was evaluated on the degradation of rice straw by varying the initial carbon/nitrogen ratio of the compost piles. Consortia of three potent cellulosedegrading fungal strains: Aspergillus fumigatus, Aspergillus terreus and Aspergillus flavus were used as an inoculant to degrade rice straw in a 90-day composting process. The carbon/nitrogen ratio of the composting piles was varied by varying the proportion of bedding material in different treatments. The composts thus achieved were subjected to physic-chemical analysis and phytotoxicity assay using Solanum lycopersicum as test seeds. After 90 days of composting, compost from treatment 4 with initial carbon/nitrogen ratio 34 depicted maximum stability by achieving a final carbon/nitrogen ratio of 16.25. Compost from treatment 4 showed the highest Germination Index (\%) followed by treatment 3 and treatment 2 as $94.32 \%, 88.88 \%$ and $79 \%$, respectively on the growth of Solanum lycopersicum seeds. Results concluded that fungal consortia derived agro-waste compost with an initial carbon/nitrogen ratio 34 depicted the earliest maturity which is suggestive of its suitability for agricultural application.
\end{abstract}

\section{INTRODUCTION}

Crop residue management is currently a global challenge. The quantity of agricultural waste generated throughout the world is enormous. Also, the problem of pollution associated with the conventional waste disposal methods demands exploration of alternative and environment-friendly methods of dealing with agro-wastes. The demand for food has been consistently increasing with the increasing population and has, therefore, created a need for upgrading of agricultural by-products. Disposal of such a huge quantity of lignocellulosic wastes is a big challenge to our environment. Wood and crop residue burning for energy leads to a release of toxic gases that cause environmental pollution (Tuomela et al. 2000). The accumulation of agro-waste raises health, safety, environmental, and aesthetic concern. Therefore, safe disposal techniques need to be explored. Crop residue management is currently a global challenge. The Ministry of New and Renewable Energy (MNRE) has reported that about $500 \mathrm{Mt}$ of agro-wastes are produced every year wherein cereals are found to produce most of the residues (352 Mt). Fibres (66 Mt), oilseeds (29 Mt), legumes (13 Mt) and sugarcane $(12 \mathrm{Mt})$ are also produced subsequently. $70 \%$ of agro-waste is contributed by rice, wheat, maize and millets collectively whereas $34 \%$ is generated from rice crop alone (Jain et al. 2014).

Rice (Oryza sativa L.) is a major crop, grown worldwide producing a large amount of rice straw. Rice straw is a stringy, lingo-cellulosic rice crop residue that remains after the harvest. It is not considered a good substrate owing to its complex lingo-cellulosic composition that renders it hard to degrade. Wastes obtained from plants, like rice straw, are unmanageable due to their lignin content which interferes with biodegradation (Van Soest 2006). Rice straw constitutes a considerable amount of silica which exhibit various repercussions related to animal health problems and grants this crop residue a gruff appearance thereby weakening its suitability for animal intake due to its reduced digestibility. The direct incorporation of straw in the soil is coupled with problems like immobilization of plant nutrients especially nitrogen and reduces the germination of crop seeds. It can hamper seedbed preparation and add to disease and weed problems. Therefore, at present, there are limited options for rice straw because of its pitiable quality for forage, bioconversion, and engineering applications. Rice straw is usually not integrated in the crop field due to its protracted rate of decomposition and susceptibility to pest invasion (Nigam \& Pandey 2009). 
Farmers generally opt for open field burning to get rid of this crop residue thereby contributing to greenhouse emissions into the atmosphere. A significant amount of rice straw is burned on-farm to make way for the succeeding wheat crop. Stubble burning results in air pollution which has dire consequences on the ecosystem due to the deteriorating soil quality, soil erosion, intensification of air pollutants and greenhouse gases (Gadde et al. 2009). 80\% of rice straw is burnt in Punjab, Himachal Pradesh and Haryana while 50\% is burnt in Karnataka and 25\% in the state of Uttar Pradesh (Gupta et al. 2003). This in situ burning of rice straw can be attributed to the modern method of harvesting done with the aid of combine harvesters. To tackle this issue, composting has emerged as an eco-friendly and economic treatment technology and as an effective approach to achieve enhanced and sustainable output from agriculture (Sarkar \& Chourasia 2017). It aids in the reduction of waste volume, weight, moisture content, odour, pathogens and spread of diseases, thereby, increasing potential nutrients in the compost rendering it suitable for agricultural applications (Gautam et al. 2011). It is seen as a key process where the final product is safer to use and microbes such as fungi have proved to be beneficial in accelerating the degradation of lignocellulosic waste. Compost properties differ significantly depending on the composting feedstock and composting procedures. Carbon and nitrogen are imperative elements essential for microbial breakdown (Ain et al. 2017). Carbon provides energy and structural support and constitutes half of the cell biomass in microbes whereas nitrogen being a chief constituent of enzymes and nucleic acids helps in growth and performance of cells. It is important to consider the carbon and nitrogen $(\mathrm{C} / \mathrm{N})$ ratio of the compost components to establish the optimal amounts of carbon and nitrogen. Narrowing of $\mathrm{C} / \mathrm{N}$ ratio of agro-wastes by using urea as a supplement has been in practice earlier (Gaind \& Gaur 2000). But developments in agriculture and an increasing inclination towards organic farming has catered to the use of organic wastes rich in nitrogen. Chicken litter or poultry manure can be considered as one such alternative (Ogunwande et al. 2008). It is also recognized that when the rice straw is combined with poultry manure, it reduces the $\mathrm{C} / \mathrm{N}$ ratio of rice straw and even impedes the loss of nitrogen thereby developing an end-product which is equipped to provide required nourishment to the plants (Gaind et al. 2010).

Naturally, very few microorganisms are potent enough to break the intricate structure of lignin during composting. Fungi, owing to their potential to conceive prolific spores and filamentous morphology, are quite effective in degrading lingo-cellulosic crop residues. Also, fungi are the most influential and dominant groups present in soil which impact the structure and functioning of the ecosystem and therefore play a major role in many ecological services. Fungi produce an array of hydrolytic enzymes and hence subsist in nature in saprophytic mode and are more effective than bacteria in acidic soils and decomposing cellulose rooted in lignin (Goyal et al. 2011). They can stand a wide range of $\mathrm{pH}$ as compared to bacteria and hence are more preferred than bacteria for the decomposition of complex organic wastes. Composting of agro residues with high $\mathrm{C} / \mathrm{N}$ ratio can be efficiently achieved by inoculating cellulolytic fungi such as Aspergillus sp (Ashraf et al. 2007). Also, these fungi have been reported to slash down the duration of the composting process by one month.

Though microbes amended composting has been studied earlier but rice straw composting aided with fungal inoculation has less explored literature. In the present research, the synergistic effect of fungal consortia on the degradation of rice straw by varying initial $\mathrm{C} / \mathrm{N}$ ratio was studied and the compost thus achieved were tested for their phytotoxic effects on Solanum lycopersicum (tomato) seeds.

\section{MATERIALS AND METHODS}

For composting, paddy straw was obtained after the harvest of rice from the rice field of Kanheli village, Rohtak city (Haryana). It was then pre-treated by soaking in $0.1 \%$ urea solution and stacked along with green leaves and poultry droppings to make composting piles. Pre-treatment of rice straw with urea helped in delignification of rice straw and made it susceptible to degradation by cellulase enzyme. The proportion of green leaves and poultry droppings (Fig. 1) was varied to achieve the desired $\mathrm{C} / \mathrm{N}$ ratios in the composting piles.

Three cellulolytic fungal strains cultured at Department of Environmental Science, MDU, Rohtak were used as inoculants for composting purpose. Fungal spore suspension was prepared as per the method described by Samsudin et al. (2013). 5-day old culture slants were washed with $0.9 \%$ $\mathrm{NaCl}$ saline solution and shaken rapidly for one minute. Haemocytometer was used to count fungal spores and the number of spores was adjusted to contain approximately $10^{7}$ spores $/ \mathrm{mL}$ of each fungal isolate. A broth inoculum containing $10^{7}$ spores $/ \mathrm{mL}$ of each isolate was used for inoculation.

A 90-day experiment was conducted to degrade rice straw. Bins were set in triplicate with circular holes of $100 \mathrm{~mm}$ diameter to provide aeration to the compost material. Control bin was also set in which no inoculants were added. Prepared compost treatments have been described in Table 1. 
Table 1: Various compost treatments prepared for the study.

\begin{tabular}{|lll|}
\hline Treatment & Initial C/N ratio & Composition \\
\hline Treatment 1 & Control & No inoculants added \\
Treatment 2 & $30: 1$ & Rice straw $=2000 \mathrm{~g}$, Green Leaves $=1000 \mathrm{~g}$, Poultry droppings $=1000 \mathrm{~g}+$ Fungal Inoculants \\
Treatment 3 & $26: 1$ & Rice straw $=2000 \mathrm{~g}$, Green Leaves $=1000 \mathrm{~g}$, Poultry droppings $=1300 \mathrm{~g}+$ Fungal Inoculants \\
Treatment 4 & $34: 1$ & Rice straw $=2000 \mathrm{~g}$, Green Leaves $=1000 \mathrm{~g}$, Poultry droppings $=750 \mathrm{~g}+$ Fungal Inoculants \\
\hline
\end{tabular}
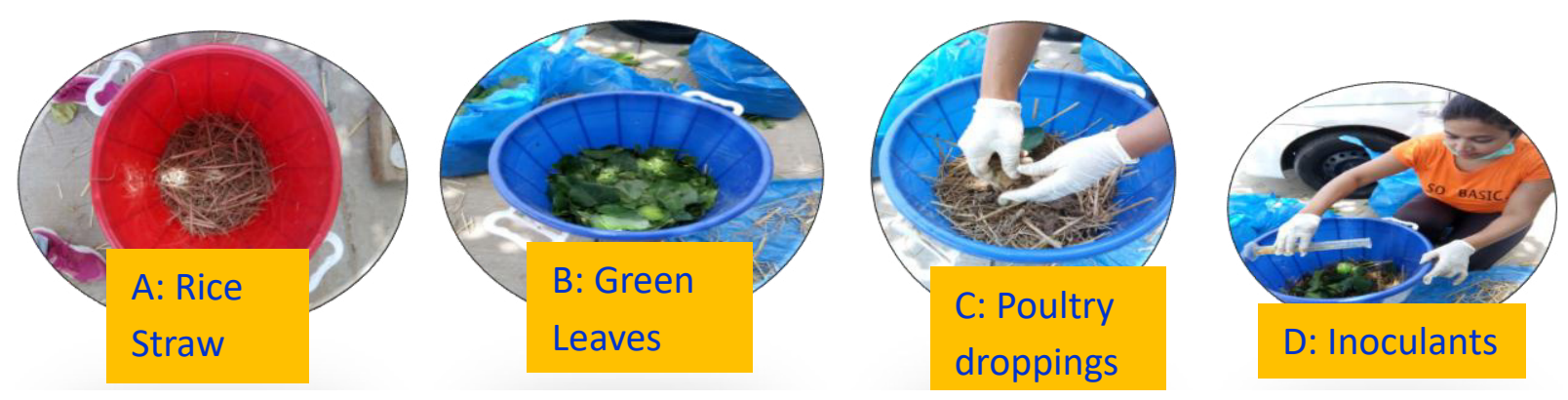

Fig.1 (A-D): Setting of compost bins.

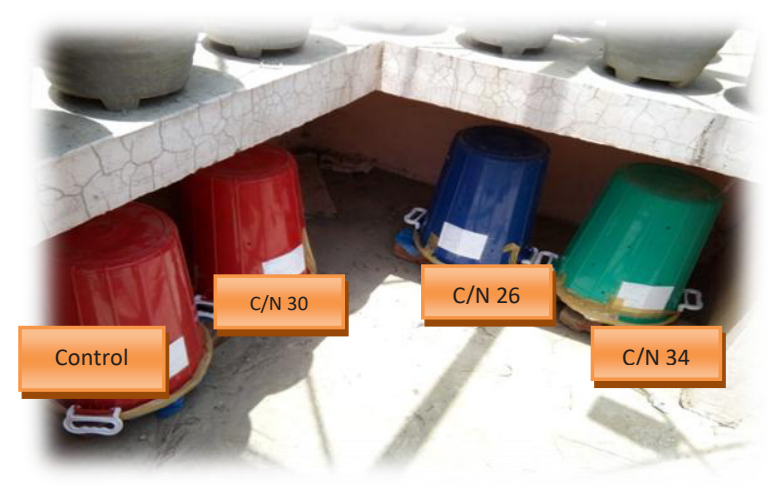

Fig. 2: Compost piles.

The compost bins were kept inverted to form heaps (Fig. 2 ). The components of the compost bins were turned at regular intervals to provide aeration (Jusoh et al. 2013). Compost samples were taken at 30,60 and 90-days intervals and were subjected to physic-chemical analysis as per standard protocols mentioned in Table 2. The mature compost obtained after 90 days was also subjected to phytotoxicity analysis to check the effectiveness of compost on the growth of test seeds Solanum lycopersicum. For this, seeds of Solanum lycopersicum were disinfected by dipping in $7 \%$ alcohol for about 3 minutes. Later it was left in a suspension of 0.001
$\mathrm{HgCl}_{2}$ for about 2 minutes where it was stirred intermittently. It was repeatedly washed with distilled water to ensure that no toxins are present. $10 \mathrm{~mL}$ volume of compost extract was poured on filter paper spread in a Petri plate. 20 sterilized seeds of Solanum lycopersicum were then set on filter paper and Petri plates were carefully sealed using tape to reduce the loss of water. They were then incubated for 72 hours at room temperature. All tests were carried out in triplicate. The percentage of root elongation, seed germination and germination index (GI) was deduced using equations 1 to 3 (Zucconi et al. 1981).

$$
\text { Seed germination }(\%)=\frac{\text { Number of seeds germinated in compost extract }}{\text { Number of seeds germinated in control }} \times 100
$$




$$
\begin{aligned}
& \text { Root elongation }(\%)=\frac{\text { Mean root length in compost extract }}{\text { Mean root length in control }} \times 100 \\
& \text { Root elongation }(\%)=\frac{\text { Mean root length in compost extract }}{\text { Mean root length in control }} \times 100
\end{aligned}
$$

\section{RESULTS AND DISCUSSION}

After 90 days of composting, the compost obtained had a uniform and granular texture, was relatively dry, earthy, and dark brown (Fig. 3). It looked crumbly and had a pleasant aroma, like freshly turned earth. Similar results were obtained by Pandharipande et al. (2004) who stated that finished compost must be black or dark brown in colour, granular and spongy with normal smell.

Results of the physic-chemical analysis of compost samples have been served in Table 3. pH alteration is crucial to plant health. Results reveal that all treatments were recorded with an alkaline $\mathrm{pH}$ to some extent in the early stages of decomposition. With due course of composting, $\mathrm{pH}$ values show signs of gradual decrease which might be

Table 2: Methods used to detect parameters in compost samples.

\begin{tabular}{|ll|}
\hline Parameters & Methods used \\
\hline $\mathrm{pH}$ & $\mathrm{pH}$ meter \\
Electrical conductivity & Conductivity meter \\
Total organic carbon & Walkley and Black method (Khiari et al. \\
& 2005) \\
Total nitrogen & Kjeldahl method (Katyal et al. 1987, Bremner \\
& 1996) \\
\hline
\end{tabular}

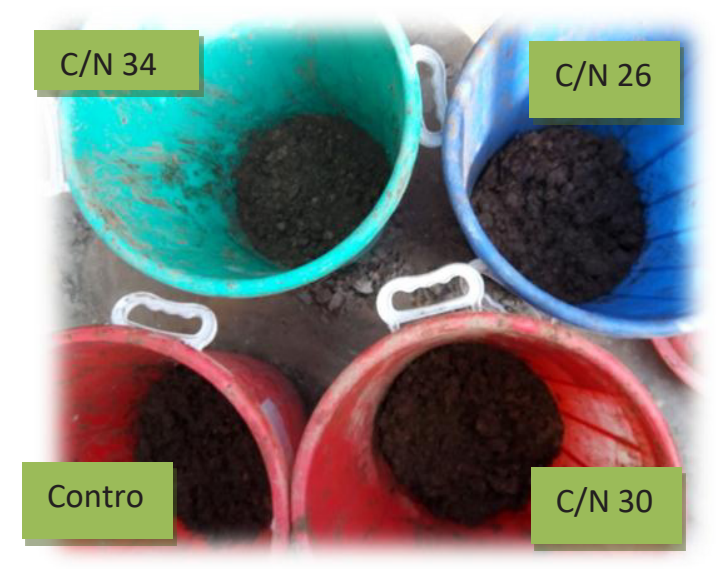

Fig. 3: Compost after 90 days of composting. due to the production of organic acids and loss of ammonia to the atmosphere. $\mathrm{pH}$ in all treatments stabilized at the end of 90 days with $\mathrm{pH} 7.5,7.1,7.2$ and 6.7 for treatments 1, 2, 3 and 4 respectively (Fig. 4). Electrical Conductivity (EC) showed an increasing trend in all treatments during composting (Fig. 5). Treatment 4 (C/N 34) showed maximum electrical conductivity $(3.6 \mathrm{dS} / \mathrm{m})$ followed by treatment 3 $(3.4 \mathrm{dS} / \mathrm{m})$ and treatment $2(3.1 \mathrm{dS} / \mathrm{m})$. The increase in EC can be attributed to an increase of potassium $\left(\mathrm{K}^{+}\right)$and other ions during composting and also due to the release of inorganic salts during decomposition (Bernal et al. 2009). EC was found to be higher in treatment 4 which might be due to the release of soluble salts (Huang et al. 2004, Wang et al. 2004). Total organic carbon (TOC) depicts a decreasing trend (Fig. 6) with value of treatment $4(18.2 \%)>$ treatment $2(18 \%)>$ treatment $3(17.4 \%)$ after 90 days of composting. This might be due to the loss of carbon in the form of $\mathrm{CO}_{2}$ as decomposition proceeds. This is in accordance with results indicated by Getahun et al. (2012). Also, the maximum value for Total Nitrogen content was observed in treatment $4(1.12 \%)$ followed by treatment $3(0.94 \%)$ and treatment 2 $(0.91 \%)$ at 90 days of composting (Fig. 7).

After 90 days of composting, treatment 4 with initial $\mathrm{C} / \mathrm{N}$ ratio 34 depicted maximum stability by achieving a final $\mathrm{C} / \mathrm{N}$ of 16.25 (Fig. 8) which shows that the compost from treatment 4 has attained earliest maturity and is suitable for agricultural application (Owis et al. 2016). On the contrary, a high $\mathrm{C} / \mathrm{N}$ in compost obtained from control treatment depicts that carbon has been left unused in the compost mixture (Dobermann \& Fairhurst 2002). This was supported by the fact that in treatment 4 , the compost showed highest Germination Index (\%) followed by treatment 3 and treatment 2 as $94.32 \%, 88.88 \%$ and $79 \%$, respectively on the growth of Solanum lycopersicum seeds (Fig. 9 \& Fig. 10) which implies that for most treatments phytotoxicity has been eliminated. Similar results were observed by Azim et al. (2014) and Abdelhamid et al. (2004). It can therefore be inferred from the study that rice straw can be efficiently degraded by lowering its initial $\mathrm{C} / \mathrm{N}$ ratio to 34 using poultry droppings as an amendment. Similar results were recorded by Kausar et al. (2014). 
Table 3: Physico-chemical analysis of composts during the 90-day study.

\begin{tabular}{|c|c|c|c|c|}
\hline Parameters & Initial C/N Ratio & 30 days of composting & 60 days of composting & 90 days of composting \\
\hline \multirow[t]{4}{*}{$\mathrm{pH}$} & $\mathrm{C} / \mathrm{N} 34$ & $7.8 \pm 0.02$ & $7.1 \pm 0.17$ & $6.7 \pm 0.26$ \\
\hline & $\mathrm{C} / \mathrm{N} 30$ & $8.1 \pm 0.13$ & $7.9 \pm 0.16$ & $7.1 \pm 0.29$ \\
\hline & $\mathrm{C} / \mathrm{N} 26$ & $7.9 \pm 0.32$ & $7.6 \pm 0.11$ & $7.2 \pm 0.16$ \\
\hline & Control & $8.3 \pm 0.11$ & $7.5 \pm 0.31$ & $7.5 \pm 0.26$ \\
\hline \multirow[t]{4}{*}{ Total Organic Carbon (\%) } & C/N 34 & $21 \pm 0.25$ & $19.7 \pm 0.19$ & $18.2 \pm 0.09$ \\
\hline & $\mathrm{C} / \mathrm{N} 30$ & $20.2 \pm 0.18$ & $19 \pm 0.27$ & $18 \pm 0.27$ \\
\hline & $\mathrm{C} / \mathrm{N} 26$ & $20 \pm 0.22$ & $18.9 \pm 0.05$ & $17.4 \pm 0.16$ \\
\hline & Control & $21 \pm 0.15$ & $20.3 \pm 0.01$ & $19.8 \pm 0.22$ \\
\hline \multirow{4}{*}{$\begin{array}{l}\text { Total Nitrogen } \\
(\%)\end{array}$} & C/N 34 & $0.65 \pm 0.06$ & $0.78 \pm 0.16$ & $1.12 \pm 0.07$ \\
\hline & C/N 30 & $0.79 \pm 0.37$ & $0.88 \pm 0.25$ & $0.91 \pm 0.13$ \\
\hline & C/N 26 & $0.78 \pm 0.23$ & $0.86 \pm 0.18$ & $0.94 \pm 0.27$ \\
\hline & Control & $0.71 \pm 0.19$ & $0.73 \pm 0.16$ & $0.73 \pm 0.21$ \\
\hline \multirow{4}{*}{$\begin{array}{l}\text { Electrical Conductivity } \\
(\mathrm{dS} / \mathrm{m})\end{array}$} & C/N 34 & $2.7 \pm 0.04$ & $3.1 \pm 0.07$ & $3.6 \pm 0.15$ \\
\hline & $\mathrm{C} / \mathrm{N} 30$ & $2.3 \pm 0.12$ & $2.7 \pm 0.16$ & $3.1 \pm 0.19$ \\
\hline & $\mathrm{C} / \mathrm{N} 26$ & $2.4 \pm 0.26$ & $2.9 \pm 0.11$ & $3.4 \pm 0.34$ \\
\hline & Control & $2.3 \pm 0.08$ & $2.5 \pm 0.13$ & $2.8 \pm 0.28$ \\
\hline \multirow[t]{4}{*}{$\mathrm{C} / \mathrm{N}$ ratio } & C/N 34 & $32.3 \pm 0.05$ & $24.8 \pm 0.18$ & $16.25 \pm 0.17$ \\
\hline & C/N 30 & $25.5 \pm 0.14$ & $21.5 \pm 0.04$ & $19.7 \pm 0.04$ \\
\hline & $\mathrm{C} / \mathrm{N} 26$ & $25.6 \pm 0.12$ & $21.9 \pm 0.25$ & $18.5 \pm 0.16$ \\
\hline & Control & $29.5 \pm 0.18$ & $27.8 \pm 0.07$ & $27.1 \pm 0.11$ \\
\hline
\end{tabular}

$(\mathrm{n}=3 ;$ Mean $\pm \mathrm{SD})$

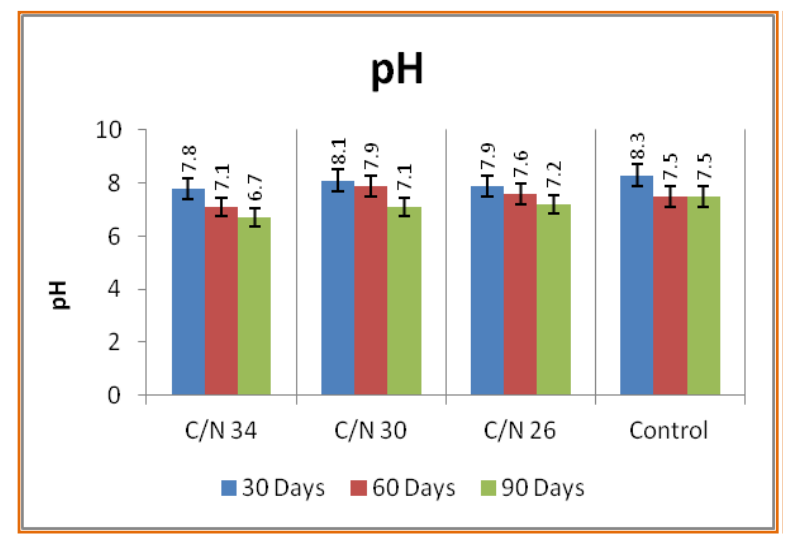

Fig. 4: $\mathrm{pH}$ values during composting.

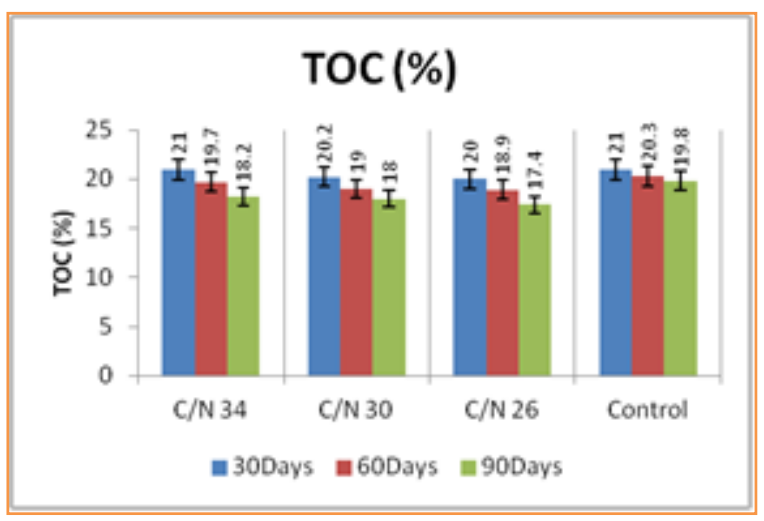

Fig. 6: Total organic carbon in compost samples.

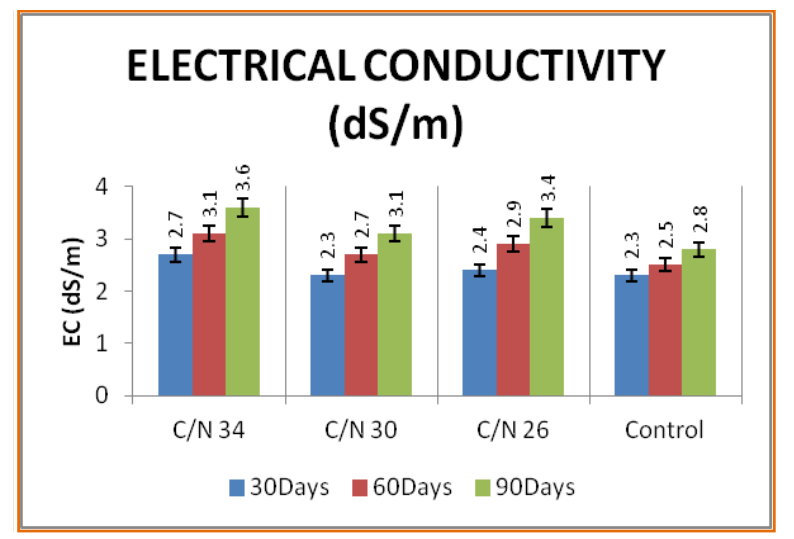

Fig. 5: Electrical conductivity (dS/m) of compost.

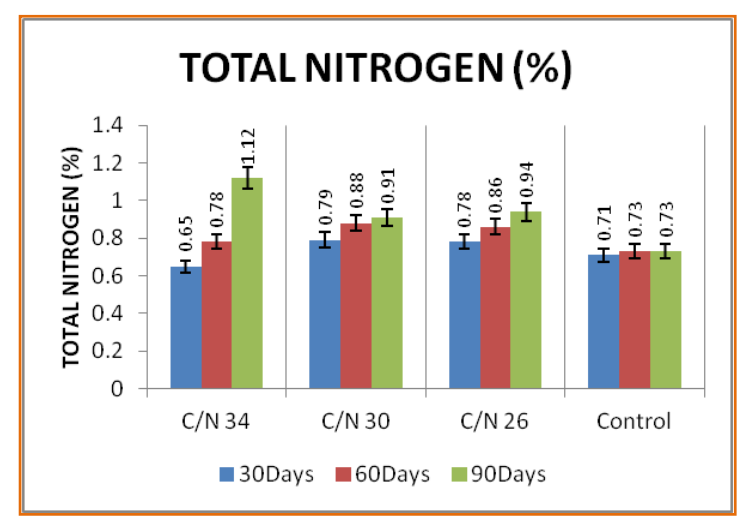

Fig. 7: Total nitrogen content in compost samples. 


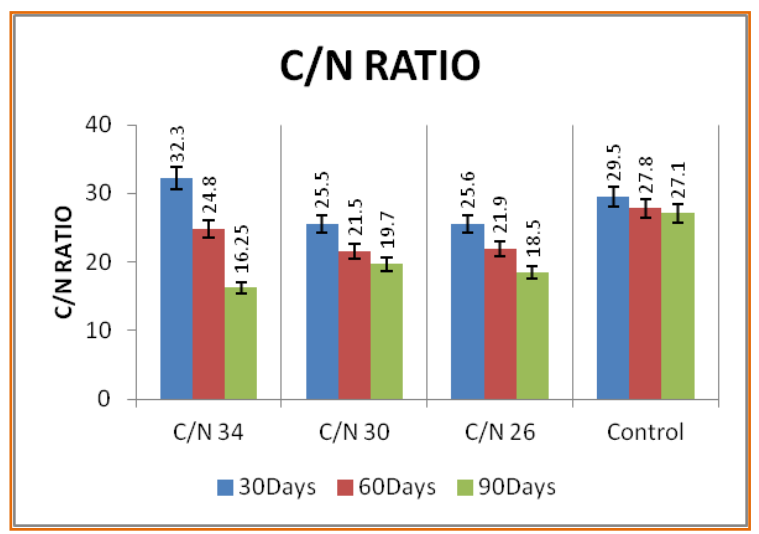

Fig. 8: $\mathrm{C} / \mathrm{N}$ ratio of compost samples.

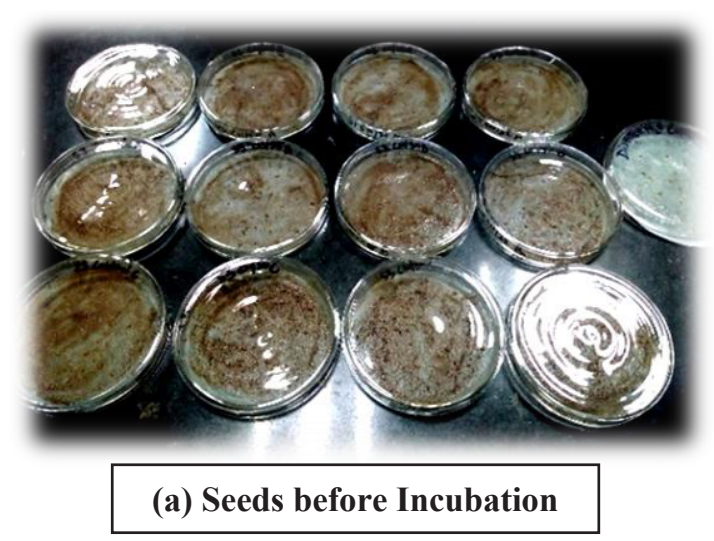

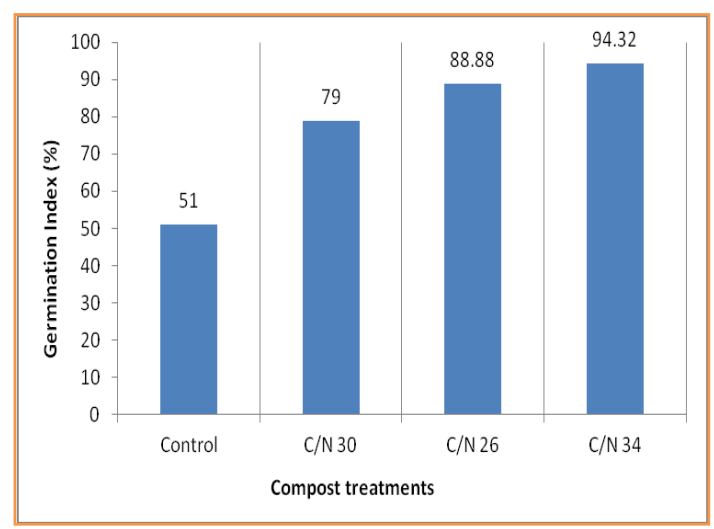

Fig. 9: Germination index (\%) of final composts at the end of 90 days of composting.

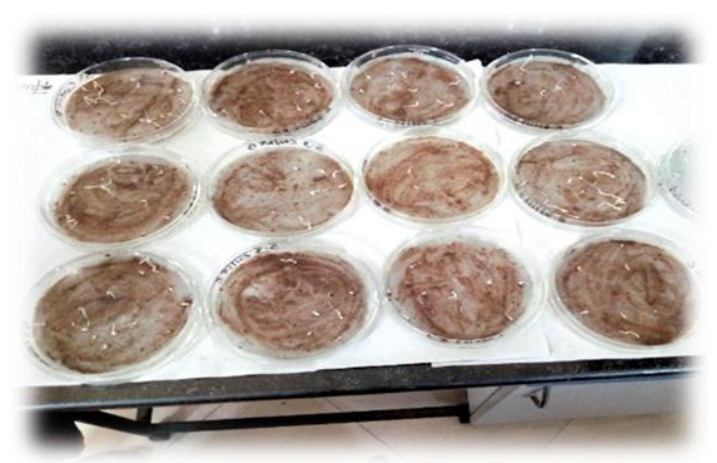

(b) Seeds after 72 hours of incubation

Fig.10 (a-b): Germination Index of mature compost.

Table 4: ANOVA: Two-factor without replication.

\begin{tabular}{|llllll|}
\hline Source of variation & SS & df & MS & F & P-value \\
\hline Rows & 5237.736173 & 13 & 402.9027826 & 1.987737096 & $1.02707 \mathrm{E}-28$ \\
Columns & 21.83360536 & 3 & 7.277868452 & 2.595262191 & 0.046159652 \\
Error & 109.3673196 & 39 & 2.804290247 & & 2.845067805 \\
Total & 5368.937098 & 55 & & & \\
\hline
\end{tabular}

*null hypothesis is rejected and significant difference exists between the treatments

\section{Statistical Analysis}

To deduce the variables involved in inferring the compost quality, through physic-chemical characteristics and their relationships with each other, Two-way ANOVA (Table 4) and Pearson correlation coefficient (Table 5) were applied using SPSS 23.0 (0.05 levels).

\section{CONCLUSION}

The consortia of Aspergillus fumigatus, Aspergillus terreus and Aspergillus flavus efficiently degraded rice straw, thereby reducing the decomposition time. The final values of $\mathrm{C} / \mathrm{N}$ observed in treatments 2, 3 and 4 are considered as acceptable levels for compost maturity. It is evident from the study 


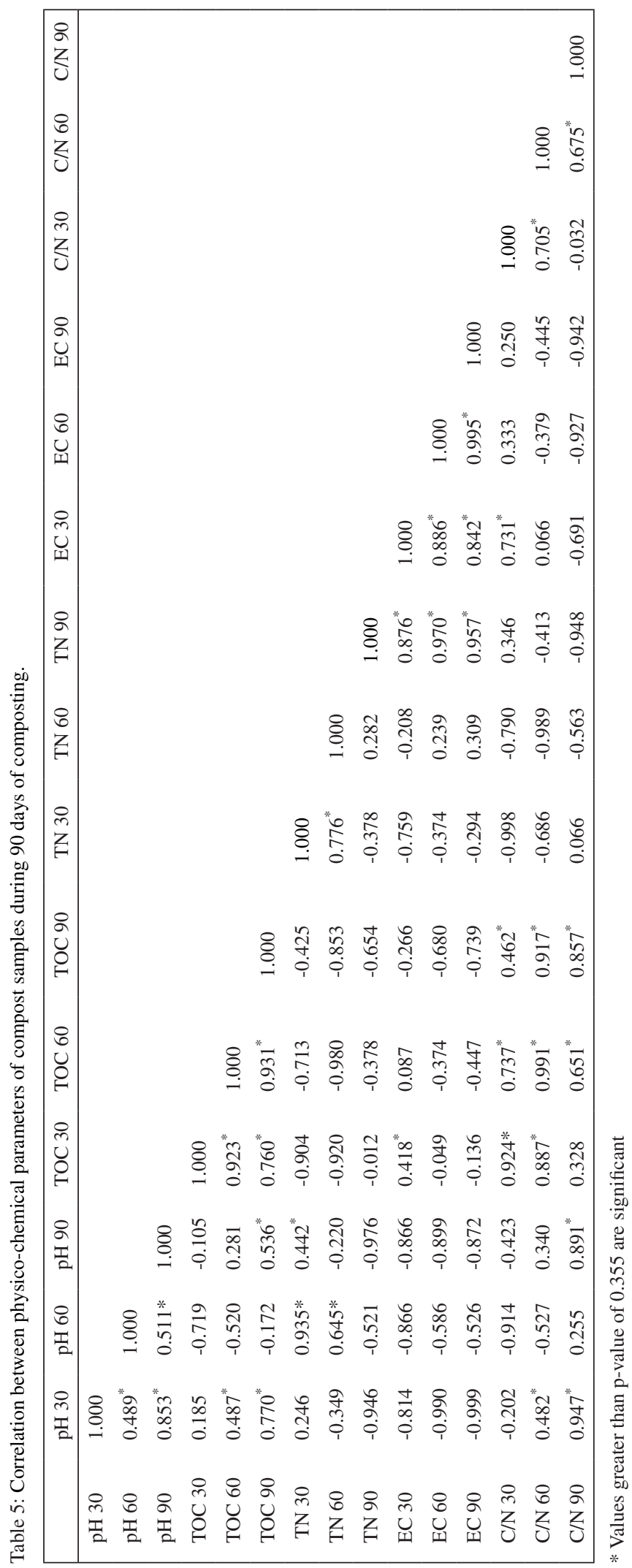


that composts attained maturity in 90 days and possessed a good amount of nutrients and organic matter. Moreover, no signs of phytotoxicity were detected in the final composts, except in control treatment. This study illustrates that supplementing rice straw with poultry droppings helped enhance the quantity of organic compounds in the final product. The study also indicates that reducing the initial $\mathrm{C} / \mathrm{N}$ of rice straw to 34 by combining it with poultry droppings and inoculating with Aspergillus strains produced good quality mature compost as compared to the treatment done without using any inoculants. It can, therefore, be concluded that rice straw can be efficiently degraded by reducing its initial $\mathrm{C} / \mathrm{N}$ ratio to 34 by amending it with poultry droppings and using a consortium of Aspergillus fumigatus, Aspergillus terreus and Aspergillus flavus as an inoculant. The compost thus formed can be deemed suitable for agricultural applications.

Thus we need to resort to composting rather than burning rice straw. Composting of crop residues is a promising avenue to create employment for people and it will also help to deal with the problem of increasing air pollution caused due to stubble burning.

\section{REFERENCES}

Abdel-Hamid, M.T., Horuchi, T. and Oba, S. 2004. Composting of rice straw with oilseed rape cake and poultry manure and its effects on faba bean (Vicia faba L.) growth and soil properties. Bioresour. Technol., 93: 183-189.

Ain, A.N., Hariz, A.M., Fariza, M.N. and Alyani, S.N. 2017. Physico-chemical and microbiological study during conventional composting using different rates of rice straw and cattle manure mixture. J. Trop. Agric. And Fd. Sci., 45(2): 145-154.

Ashraf, R., Shahid, F. and Ali, T.A. 2007. Association of fungi, bacteria and actinomycetes with different composts. Pak. J. Bot., 39 (6): 2141-2151.

Azim, K., Ouyihya, K., Amellouk, A., Perissol, C., Thami Alami, I. and Soudi, B. 2014. Dynamic composting optimization through C/N ratio variation as a startup parameter. Building Organic Bridges, 3: 787-790.

Bernal, M.P., Alburquerque, J.A. and Moral, R. 2009. Composting of animal manures and chemical criteria for compost maturity assessment. A review. Bioresour. Technol., 5453-5444:(22)100.

Bremner, J.M. 1996. Nitrogen-Total. DL Sparks (ed.) Methods of Soil Analysis. Part 3, SSSA Book Ser. 5. SSSA, Madison, WI p. 10851121.

Dobermann, A. and Fairhurst, T.H. 2002. Rice straw management. BCI, 16 (1): 7-11.

Gadde, B., Bonnet, S., Menke, C. and Garivait, S. 2009. Air pollutant emissions from rice straw open field burning in India, Thailand and the Philippines. Environ. Pollut., 157 (5): 1554-1558.

Gaind, S. and Gaur, A.C. 2000. Effect of microbial inoculants and levels of Mussoorie rock phosphate on the quality of organo-biofertilizer. Geobios., 27 (1): 21-24.
Gaind, S. and Nain, L. 2010. Exploration of composted cereal waste and poultry manure for soil restoration. Bioresour. Technol., 101 (9): 2996-3003.

Gautam, S.P., Bundela, P.S., Pandey, A.K., Awasthi, M.K. and Sarsaiya, S. 2011. Isolation, identification and cultural optimization of indigenous fungal isolates as a potential bioconversion agent of municipal solid waste. Annals of Environmental Science, 5 (1): 4.

Getahun, T., Mengistie, E., Haddis, A., Wasie, F., Alemayehu, E., Dadi, D., Gerven, T.V. and Van der Bruggen, B. 2012. Municipal solid waste generation in growing urban areas in Africa: current practices and relation to socioeconomic factors in Jimma, Ethiopia. Environ. Monit. Assess., 184 (10): 6337-6345.

Goyal, S. and Sindhu, S.S. 2011. Composting of rice straw using different inocula and analysis of compost quality. J. Microbiol., 1(4): 126-138.

Gupta, R.K., Naresh, R.K., Hobbs, P.R., Jiaguo, Z. and Ladha, J.K. 2003. Sustainability of post-green revolution agriculture: the rice-wheat cropping systems of the Indo-Gangetic Plains and China. Improving the Productivity and Sustainability of Rice-wheat Systems: Issues and Impacts, 65: 1-25.

Huang, G.F., Wong, J.W.C., Wu, Q.T. and Nagar, B.B. 2004. Effect of $\mathrm{C} / \mathrm{N}$ on composting of pig manure with sawdust. Waste Manage., (Oxford), 24 (8): 805-813.

Jahromi, M.F., Liang, J.B., Rosfarizan, M., Goh, Y.M., Shokryazdan, P. and Ho, Y.W. 2011. Efficiency of rice straw lignocelluloses degradability by Aspergillus terreus ATCC 74135 in solid state fermentation. African Journal of Biotechnology, 10(21): 4428-4435.

Jain, N., Bhatia, A. and Pathak, H. 2014. Emission of air pollutants from crop residue burning in India. Aerosol Air Qual Res., 14 (1): 422-430.

Jusoh, M.L.C., Manaf, L.A. and Latiff, P.A. 2013. Composting of rice straw with effective microorganisms (EM) and its influence on compost quality. J. Environ. Health Sci., 10(1): 17.

Katyal, J.C., Singh, B., Vlek, P.L.G. and Buresh, R.J. 1987. Efficient nitrogen use as affected by urea application and irrigation sequence. Soil Sci. Soc. Am. J., 51(2): 366-370.

Kausar, H., Ismail, M.R., Saud, H.M., Habib, S.H., Othman, R. and Bhuiyan, M.S.H. 2014. Changes of physical and chemical characteristics during microbial composting of rice straw at various $\mathrm{pH}$ levels. Compost Sci. Util., 163-153:(3)22.

Khiari, L. and Parent, L.E. 2005. Phosphorus transformations in acid light-textured soils treated with dry swine manure. Can. J. Soil Sci., 87-75:(1)85.

Nigam, P.S.N. and Pandey, A. eds., 2009. Biotechnology For Agro-Industrial Residues Utilisation: Utilisation of Agro-Residues. Springer Science \& Business Media.

Ogunwande, G.A., Osunade, J.A., Adekalu, K.O. and Ogunjimi, L.A.O. 2008. Nitrogen loss in chicken litter compost as affected by carbon to nitrogen ratio and turning frequency. Bioresour. Technol., 99 (16): 7495-7503.

Owis, A.S., El-Etr, W.M., Badawi, F.S.F., El-soud, A.A. and Abdel-Wahab, A.F.M. 2016. Bioprocessing the crop residues with different amendments for producing high quality compost. Int. J. Chemtech Res., 9: 43-54.

Pandharipande, S.L., Gadekar, S. and Agrawal, R. 2004. Bio conservation of press mud (a waste from sugar industry). Asian. Jr. of Microbiol. Biotech. Env., 6(1): 87-88.

Sarkar, P. and Chourasia, R. 2017. Bioconversion of organic solid wastes into biofortified compost using a microbial consortium. Int. J. Recycl. Org. Waste Agric., 4)6): 321-334.

Tuomela, M., Vikman, M., Hatakka, A. and Itävaara, M. 2000. Biodeg- 
radation of lignin in a compost environment: a review. Bioresour. Technol., 183-169:(2) 72.

Van Soest, P.J. 2006. Rice straw, the role of silica and treatments to improve quality. Animal Feed Science and Technology, 130 (3-4): 137-171.
Wang, P., Changa, C.M., Watson, M.E., Dick, W.A., Chen, Y. and Hoitink, H.A.J. 2004. Maturity indices for composted dairy and pig manures. Soil Biol. Biochem., 776-767:(5)36.

Zucconi, F. 1981. Evaluating toxicity of immature compost. Biocycle, 22(2): 54-57. 